\title{
Kajian Analisa Konsep Penanganan Drainase dalam menunjang Pengelolaan Air pada Permukiman Tepian Sungai Kapuas Pontianak
}

\author{
Eva Ryanti, Pramudya Kurniawan, \& Ida Zuraida \\ Jurusan Teknik Sipil, Politeknik Negeri Pontianak \\ Jalan Ahmad Yani, Pontianak Tenggara, Pontianak 78124 \\ Email: evaryantipolnep@gmail.com
}

\begin{abstract}
This research discuss about the concept analysis for drainase transaction in the residential at kapuas riverbank according to the catchment area. It is evidence that the construction and the structure function are developing to the commercial area which led to the economic growth. The researcher used case study approaches in the urban area at kapuas river bank, and aplicated the literature data for analysing the rainfall and domestic water waste as well as public facilities. Furthermore, this research focused on three aspects; firstly, the descriptive analysis for hydrology to know the debit plans by rational method, secondly, the hidrolika analysis to get canal dimension, and the last, to find the water storage necessity. So, the aims of this research are to verify the drainase system in the kapuas riverbank pontianak especially at Benua Melayu Laut (BML) territory, and to have the problem solving of floods caused by rainfall and waste water, also to find out the necessity of water storage in that area. In brief, debit plan for the rainfalls and waste water were earned from the catchment area according to direction of water flow in drainare canal plan at BML. As well as channel view dimension was earned by the available debit plan. Then the water storage is unnecessary in $B M L$.
\end{abstract}

Keywords: residential, drainage, analysis

Abstrak: Penelitian ini mengkaji analisa konsep penanganan drainase permukiman tepian Sungai Kapuas Pontianak berdasarkan cacthment area, terjadi peningkatan pembangunan dan perubahan fungsi bangunan menjadi daerah komersial sehingga berkembangnya aktifitas ekonomi. Dengan menggunakan pendekatan studi kasus yakni kawasan permukiman padat yang berada di tepian sungai, dengan teknik studi literatur untuk menganalisa air hujan dan air buangan dari rumah tangga dan fasilitas umum. aspek yang dipertimbangkan dan komponen yang diatur dalam kajian, analisis deskriptif untuk analisa hidrologi mendapatkan debit rencana menggunakan metode rational serta analisa hidrolika untuk mendapatkan dimensi saluran dan perlu tidaknya membuat kolam penampungan. Sehingga keutamaan penelitian ini memuat beberapa tujuan yang akan dicapai yaitu: untuk mengkaji sistem drainase yang ada di tepian sungai kapuas pontianak khususnya kelurahan Benua Melayu Laut (BML), untuk mendapatkan penyelesaian masalah banjir akibat air hujan dan air buangan dari rumah tangga dan fasilitas umum, serta perlu tidaknya dibuat kolam penampungan. Debit rencana dari data hujan dan air buangan didapat dari setiap catchment area berdasarkan arah aliran air dari rencana saluran drainase di kawasan BML dan didapat dimensi penampang saluran dari debit rencana yang ada. Tidak diperlukan kolam penampungan di Kawasan BML.

Kata kunci: Permukiman, drainase, analisa

Permukiman berfungsi sebagai lingkungan tempat tinggal/hunian dan tempat kegiatan yang mendukung perikehidupan dan penghidupan. Merupakan suatu masalah yang 
kompleks yang berhubungan dan terkait dengan sosial, ekonomi, budaya, ekologi, dan sebagainya. Kompleksitas yang terjadi dalam permukiman adalah suatu hal yang wajar mengingat hakekat dan fungsi permukiman begitu luas dalam kehidupan manusia, walaupun tidak dengan sendirinya berarti selalu diperhatikan dan diperhitungkan. Fokus riset keberlanjutan tidak lagi hanya sebatas persoalan lingkungan alami dalam pemahaman ekologi global (kualitas udara, air, keragaman hayati, tanah, mineral dan energi), tapi juga kepada lingkungan binaan manusia, seperti bangunan, infrastruktur, ruang terbuka dan warisan bersejarah). Permukiman tepian sungai memiliki potensi dan permasalahan yang beragam. Selain potensi dari air sungai potensi lainnya adalah dalam memenuhi kebutuhan manusia berdasarkan sifatnya, yaitu kebutuhan rohani. Kebutuhan rohani merupakan kebutuhan yang berkaitan dengan jiwa seseorang misalnya ketenangan, kebutuhan rekreasi, bersosialisasi dan melakukan atau menikmati aktivitas berkesenian.

Terpenuhinya kebutuhan yang berkaitan dengan jiwa seperti rekreasi. Sosialisasi dan lain-lain yang mana kebutuhan ini diperlukan manusia juga dalam mempertahankan hidupnya diperhatikan oleh pemerintah kota Pontianak dan juga dalam rangka pengembangan pembangunan infrastruktur di tepi sungai, maka pemerintah Kota membangun Water Front City (WFC) yang terletak di Kelurahan Benua Melayu Laut (BML). Seiring dengan pertumbuhan penduduk dan peningkatan aktivitas ekonomi, pemanfaatan dan pengelolaan air dalam kehidupan menghadapi persoalan seperti pengeksploitasian air secara berlebihan, menurunkan fungsi daerah aliran sungai sebagai daerah resapan air dan peningkatan ruang terbangun menyebabkan pengurangan ruang terbuka hijau. Akibat dari semua itu adalah terjadinya banjir pasang di permukiman dan penurunan kualitas dan kuantitas air. Permasalahan air pada daerah permukiman menjadi sangat penting karena memerlukan adanya pengelolaan air yaitu pengelolaan air bersih, pengelolaan sanitasi dan drainase. Fokus masalah adalah drainase

Kelurahan BML merupakan permukiman padat penduduk, terjadi peningkatan pembangunan dan perubahan fungsi bangunan sehingga berkembangnya aktifitas ekonomi, menjadi daerah komersial dan juga dengan dibangunnya WFC sebagai jogging track, tempat bersantai dan juga cafe menyebabkan banyaknya pelebaran jalan dan peningkatan jalan dari gertak menjadi jalan permanen, permasalahan drainase di BML adalah sudah ada saluran-saluran drainase, tapi belum keseluruhan kawasan tersedia saluran drainase untuk menampung air larian dari hujan maupun dari buangan rumah tangga maupun dari fasilitas umum. Perencanaan saluran drainase dibuat bukan berdasarkan catchment area tetapi lebih berdasarkan ketersediaan dana yang tersedia (wawancara dengan bu lurah BML), sehingga lokasi dari pembangunan saluran tersebut masih acak dan tersebar tidak merata, sehingga ada kawasan yang ada drainasenya dan ada yang tidak ada, menyebabkan banjir pasang pada waktu musim hujan. Drainase diperlukan untuk mengendalikan air hujan yang berlebihan sehingga tidak terjadi bencana banjir.

Drainase merupakan salah satu fasilitas dasar yang dirancang sebagai sistem guna memenuhi kebutuhan masyarakat dan merupakan komponen penting dalam perencanaan kota (perencanaan infrastruktur khususnya). Prasarana drainase disini berfungsi untuk mengalirkan air permukaan ke badan air (sumber air permukaan dan bawah permukaan tanah) dan atau bangunan resapan. Selain itu juga berfungsi sebagai pengendali kebutuhan 
air permukaan dengan tindakan untuk memperbaiki daerah becek, genangan air dan banjir, sehingga memberikan lingkungan yang sehat, bersih, nyaman dan aman dalam beraktivitas.

\section{METODE}

Metode penelitian yang digunakan adalah dengan melakukan observasi lapangan untuk memperoleh gambaran kondisi, karakteristik serta rumusan persoalan yang terkait dengan analisa drainase pada kawasan permukiman tepian sungai Kapuas khususnya Kelurahan Benua Melayu Laut. Perolehan data sekunder dilakukan melalui studi literatur dan survei instansi terkait. Metode analisis yang digunakan adalah analisis deskriptif kualitatif dengan paradigma rasionalistik untuk mendeskripsikan pendekatan konsep drainase pada permukiman tepian sungai, sehingga nantinya dapat dianalisa. Sedangkan analisis deskriptif digunakan untuk menerapkan perlu tidaknya dibuat kolam penampungan. Dalam penelitian ini data yang digunakan terdiri dari data primer dan data sekunder. Data primer antara lain yang berhubungan dengan kondisi permukiman di tepian sungai dan sarana prasarana infrastruktur yang ada di lokasi amatan. Penerapan metode kualitatif dengan pendekatan rasionalistik pada penelitian ini adalah dengan mengadakan eksplorasi teori tentang sistem drainase Teknik penyajian data yang digunakan dalam penelitian ini meliputi data naratif, data tabel, dan data peta. Analisa perencanaan drainase untuk kawasan permukiman meliputi debit rencana dan dimensi saluran drainase.

\section{HASIL}

Tabel 1. Kondisi eksisting saluran di Lokasi Perencanaan

\begin{tabular}{|c|c|c|c|c|c|c|c|}
\hline Lokasi & $\begin{array}{c}\text { Ada/ } \\
\text { Tidak Ada } \\
\text { Saluran } \\
\end{array}$ & $\begin{array}{c}\text { Panjang } \\
\text { Jalan (M) }\end{array}$ & $\begin{array}{c}\text { Lebar Jalan } \\
\text { (M) }\end{array}$ & $\begin{array}{c}\text { Lebar } \\
\text { Saluran } \\
(\mathrm{M}) \\
\end{array}$ & $\begin{array}{c}\text { Dalam } \\
\text { Saluran (M) }\end{array}$ & Struktur & Ket. \\
\hline J1. Indragiri & Ada & 190 & 3 & 0.15 & 0.8 & Beton & \\
\hline Jl. Mahakam & Ada & 100 & 6 & 0.4 & 0.5 & Beton & \\
\hline Jl. Pangsuma & Ada & 100 & 5 & 0.4 & 0.4 & Beton & \\
\hline Gg. Fajar & Tidak ada & & 1.5 & & & & \\
\hline Gg. Kirana 2 & Ada & 50 & 2 & & & & \\
\hline J1. Barito & Ada & 60 & 6 & 0.4 & 0.4 & Beton & \\
\hline Gg. Malaya & Tidak ada & & 1.5 & & & & \\
\hline Gg. Sampit & Ada & 30 & 2 & 0.2 & 0.3 & Beton & \\
\hline Gg. Irian & Ada & 75 & 3 & 0.35 & 0.6 & Beton & \\
\hline Gg. H. Thaha & Tidak ada & & 1 & & & & \\
\hline Gg. Landak & ada & 60 & 3 & 0.3 & 0.5 & Beton & \\
\hline Gg. Aden 1 & Tidak ada & & 1.5 & & & & \\
\hline Gg. Aden 2 & Tidak ada & & 1.5 & & & & parit \\
\hline Gg. Bayu & ada & 20 & 2 & & & & parit \\
\hline Gg. Satu & Tidak ada & & 1 & & & & \\
\hline Gg. Tiga & Tidak ada & & 2 & & & & parit \\
\hline Gg. Asean & Tidak ada & & 1.5 & & & & parit \\
\hline Rangon & Tidak ada & & 1 & & & & parit \\
\hline Kamboja Baru & Tidak ada & & 1.5 & & & & parit \\
\hline Sutera & ada & 30 & 1.5 & & & & parit \\
\hline Kamboja & Tidak ada & & 2 & & & & parit \\
\hline Martapura 3 & Tidak ada & & 3 & & & & \\
\hline Martapura 2 & Tidak ada & & 3 & & & & \\
\hline Martapura Baru & ada & 35 & 3 & 0.55 & 0.4 & Beton & \\
\hline Perintis 1 & ada & 40 & 1.5 & 0.5 & 0.5 & Beton & \\
\hline H. Mursid 1 & Tidak ada & & 2.5 & & & & \\
\hline H. Mursid & Tidak ada & & 2.5 & & & & \\
\hline
\end{tabular}




\begin{tabular}{llcccccc}
\hline Rawa Indah & ada & 30 & 2.5 & 0.5 & 0.55 & Beton & \\
Garuda 1 & Tidak ada & & 2 & & & & \\
Garuda Baru & Tidak ada & & 2.5 & & & & parit \\
Garuda II & Tidak ada & & 2 & & \multirow{2}{*}{0.3} & Beton & \\
Peniti Baru & ada & 45 & 2 & 0.15 & & & parit \\
Peniti 1 & Tidak ada & & 3 & & & parit \\
Peniti 2 & Tidak ada & & 2.5 & & & parit \\
Kuantan & Tidak ada & 3 & & &
\end{tabular}

Sumber: Data lapangan 2019

Tabel 2. Data curah Hujan Harian Maksimum Tahunan

\begin{tabular}{ccc}
\hline No & Tahun & $\begin{array}{c}\text { Data curah hujan harian } \\
\text { maksimum tahunan (mm) }\end{array}$ \\
\hline 1 & 2005 & 116 \\
2 & 2006 & 94.9 \\
3 & 2007 & 124.8 \\
4 & 2008 & 135.5 \\
5 & 2009 & 150.7 \\
6 & 2010 & 108.3 \\
7 & 2011 & 105.4 \\
8 & 2012 & 77 \\
9 & 2013 & 139.5 \\
10 & 2014 & 115.7 \\
11 & 2015 & 111.3 \\
12 & 2016 & 183.7 \\
13 & 2017 & 187.4 \\
14 & 2018 & 104.7 \\
\hline Sumber: & BMKG 2019 &
\end{tabular}

Tabel 3. Data Curah Hujan Harian Maksimum Tahunan dari terbesar hingga terkecil

\begin{tabular}{cccc}
\hline Tahun & $\begin{array}{c}\text { Hujan } \\
\text { Harian } \\
\text { Max } \\
(\mathbf{m m})\end{array}$ & $\begin{array}{c}\text { Deviasi } \\
(\mathbf{x}-\overline{\mathbf{X}})\end{array}$ & $(\mathbf{x}-\overline{\mathbf{x}})^{\mathbf{2}}$ \\
\hline 2017 & 187.4 & 62.071 & 3852.862 \\
2016 & 183.4 & 58.071 & 3372.291 \\
2009 & 150.7 & 25.371 & 643.709 \\
2013 & 139.5 & 14.171 & 200.829 \\
2008 & 135.5 & 10.171 & 103.458 \\
2007 & 124.8 & -0.529 & 0.279 \\
2005 & 116 & -9.329 & 87.022 \\
2014 & 115.7 & -9.629 & 92.709 \\
2015 & 111.3 & -14.029 & 196.801 \\
2010 & 108.3 & -17.029 & 289.972 \\
2011 & 105.4 & -19.929 & 397.148 \\
2018 & 104.7 & -20.629 & 425.538 \\
2006 & 94.9 & -30.429 & 925.898 \\
2012 & 77 & -48.329 & 2335.651 \\
\hline & 1754.6 & & 12924.169 \\
\hline
\end{tabular}

\section{PEMBAHASAN}

Analisa hidrologi didapat debit rencana menggunakan metode rational, dan analisa hidrolika didapat dimensi saluran drainase. Peta wilayah lokasi penelitian adalah sebagai berikut. Secara administrasi wilayah penelitian merupakan Kelurahan Benua Melayu Laut Kecamatan Pontianak Selatan. Secara administrasi daerah perencanaan ini terletak di Kelurahan Benua Melayu Laut Kecamatan Pontianak Selatan. Kelurahan Benua Melayu Laut (BML) berada 0,50 diatas permukaan laut dan merupakan wilayah bantaran sungai, rawan banjir dengan luas wilayah 13,13 Ha/1,31 Km2, dengan batas- batas wilayah: Sebelah Utara dengan Kelurahan Darat Sekip Pontianak Kota, Sebelah Selatan dengan Kelurahan Bansir Laut Pontianak Tenggara, Sebelah Barat dengan Benua Melayu arat Pontianak Selatan, Sebelah Timur dengan Kelurahan Tambelan Sampit Pontianak Timur

Personil pemerintahan Kelurahan BML mempunyai pegawai 11 orang. Jumlah RW 11 dan jumlah RT 41. Jumlah penduduk Kelurahan BML berjumlah 10.282 jiwa terdiri dari lakilaki 5.162 jiwa dan perempuan 5.120 jiwa, dengan kepadatan penduduk 1800 jiwa/ Ha. Berdasarkan hasil studi literatur bahwa kelurahan BML pertumbuhan penduduk rata pertahunnya adalah $3,05 \%$.

Sistem drainase yang dimiliki oleh jalan dan gang yang ada di Kelurahan Benua Melayu Laut ini adalah sistem drainase tertutup dan sistem drainase terbuka. Bahkan di beberapa titik di Jalan Tanjungpura sistem drainasenya ditutup oleh beton. Pada saat hujan dikhawatirkan terjadi daerah daerah genangan air akibat tidak berfungsinya sistem drainase. 
Data curah hujan yang digunakan adalah data curah hujan harian maksimum tahunan di dapat dari Badan Meteorologi, Klimatologi dan Geofisika (BMKG) Stasiun Meteorologi Kelas
I Supadio Pontianak, didapat 14 tahun dari tahun 2005 - 2018, dapat dilihat pada tabel 3.
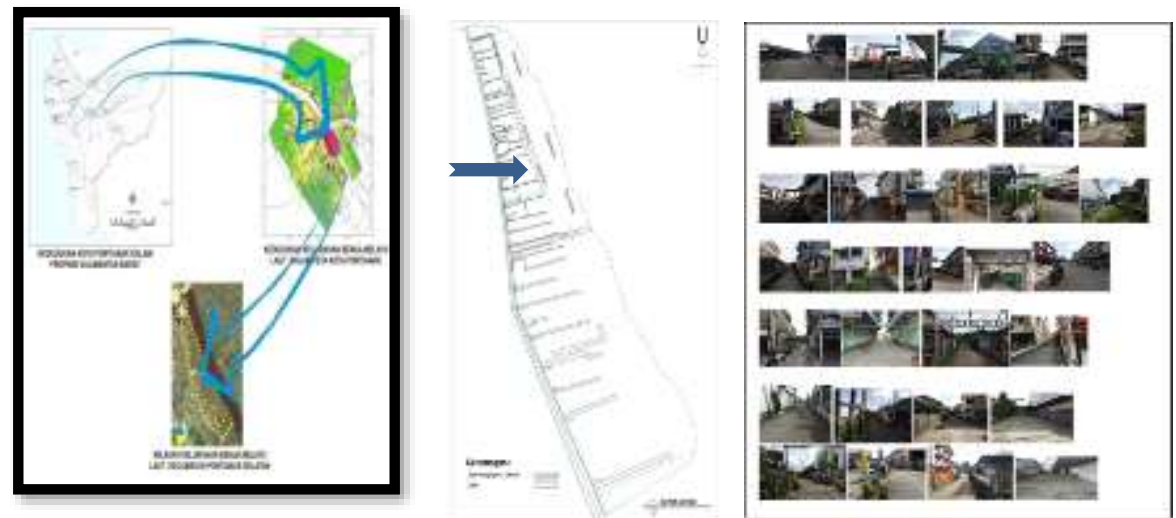

Gambar 1. Peta wilayah penelitian

\section{Analisa Hidrologi}

\section{Analisa Frekuensi Data Curah Hujan}

Pada perhitungan analisa frekuensi data curah hujan ini dihitung dengan menggunakan Metode Gumbell.

Menghitung curah hujan rata-rata $(\bar{x})$

$x=\frac{\sum x}{n}=\frac{1754.6}{14}=125.329 \mathrm{~mm}$

Menghitung Standar Deviasi ( $\mathrm{S} \overline{\mathrm{x}}$ )

$$
S x=\frac{\sqrt{\Sigma(x-x)}}{\mathrm{n}-1}=\frac{\sqrt{3852.862}}{14-1}=4.775 \mathrm{~mm}
$$

Mencari besarnya Yt, Yn, dan Sn

Kala Ulang $=5$ tahun, $\mathrm{n}=14$ tahun, maka digunakan:

$$
\begin{aligned}
& Y_{\mathrm{T}}=1.4999 \text { (untuk kala ulang } 5 \text { tahun) } \\
& \mathrm{Yn}=0.5100 \\
& \mathrm{Sn}=1.0095
\end{aligned}
$$

Mencari besarnya K

Besarnya $\mathrm{K}$ dihitung menurut rumus:

$$
\mathrm{K}=\frac{\mathrm{Yt}-\mathrm{Yn}}{\mathrm{Sn}}=\frac{1.4999-0,5100}{1.0095}=0.981
$$

Mencari besarnya curah hujan untuk periode ulang $\mathrm{R}_{\mathrm{T}}$

$\left.\mathrm{R}_{\mathrm{T}}=x+\overline{(\mathrm{K}} . \mathrm{Sx}\right)=125.329+(0.981 \times 4.775)=$ $130.013 \mathrm{~mm}$.

Menghitung Waktu Konsentrasi (Tc)

Waktu Konsentrasi air hujan untuk mengalir pada permukaan tanah menuju saluran terdekat $\left(\mathrm{t}_{\mathrm{o}}\right)$ dan saluran yang ditinjau (td) digunakan rumus :

$$
\begin{aligned}
& \text { Tc = } \mathrm{t}_{\mathrm{o}}+\mathrm{t}_{\mathrm{d}} \\
& \begin{aligned}
\mathrm{t}_{\mathrm{o}} \text { jalan } & =\left[\frac{2}{3} \cdot 3,28 \cdot \mathrm{L} \cdot \frac{\mathrm{nd}}{\sqrt{s}}\right]^{0,167} \\
& =\left[\frac{2}{3} \cdot 3,28 \cdot 1,5 \cdot \frac{0,013}{\sqrt{0,04}}\right]^{0,167} \\
& =0,773 \text { menit }
\end{aligned}
\end{aligned}
$$

t lahan luar jalan $=\left[\frac{2}{3} \cdot 3,28 \cdot \mathrm{L}_{2} \cdot \frac{\mathrm{nd}}{\sqrt{s}}\right]^{0,167}$

$$
\begin{aligned}
, & =\left[\frac{2}{3} \cdot 3,28 \cdot 50 \cdot \frac{0,02}{\sqrt{0,04}}\right]^{0,167} \\
& =1,491 \text { menit }
\end{aligned}
$$

$\mathrm{T}_{\mathrm{o}}$ total $=\mathrm{t}_{\mathrm{o}}$ jalan $+\mathrm{t}$ lahan luar jalan

$$
\begin{aligned}
& =0,773+1,491 \\
& =2,264 \text { menit } \\
\mathrm{t}_{\mathrm{d}} & =\frac{L}{60 . \mathrm{V}}=\frac{190}{60.1,50}=2.111 \text { menit }
\end{aligned}
$$

Jadi total waktu konsentrasi (tc) adalah jumlah dari $t_{o}$ dan $t_{d}$ sehingga :

$$
\begin{aligned}
\text { Tc } & =t_{o}+t_{d} \\
& =2,264+2.111 \\
& =4.375 \text { menit } \approx 0,073 \text { jam. }
\end{aligned}
$$

\section{Perhitungan Intensitas Curah Hujan (I)}

Menentukan intensitas curah hujan maksimum (mm/jam) dengan menggunakan rumus mononobe.

$$
\begin{aligned}
\mathrm{I} & =\frac{R T}{24}\left[\frac{24}{T c}\right]^{2 / 3} \\
& =\frac{130.013}{24}\left[\frac{24}{0,073}\right]^{2 / 3}
\end{aligned}
$$




$$
=147,230 \mathrm{~mm} / \mathrm{jam} \text {. }
$$

\section{Menghitung Besarnya Koefisien Pengaliran} (C)

Menghitung luas daerah pengaliran Indragiri Timur. Jalan beton, A1 $=\mathrm{L} 1 \times \mathrm{P}=190$ $\mathrm{m}^{2}$. Bagian luar jalan, $\mathrm{A} 2=\mathrm{L} 2 \times \mathrm{P}=50 \times 190=$ $9500+A_{\text {total }}=9690 \mathrm{~m}^{2}=0.00969 \mathrm{~km}^{2}$

$$
\mathrm{C}=\frac{(C 1 . A 1)+(C 2 \cdot A 2)}{A 1+A 2}
$$

$$
\begin{aligned}
& C=\frac{(0,70.190)+(0,4.9500)}{(190+9500)} \\
& C=0,406
\end{aligned}
$$

\section{Menghitung Debit Rencana Dengan Metode Rasional (Qcurah hujan)}

Rumus: $\mathrm{Q}=0$,278.C.I.A $=0,278.0,406$.

\begin{tabular}{|c|c|c|c|c|c|c|c|}
\hline Lokasi & Tc (jam) & I5 (mm/jam) & $\mathbf{C}$ & $A\left(\mathbf{k m}^{2}\right)$ & $\mathbf{Q}\left(\mathrm{m}^{3} /\right.$ detik$)$ & $\begin{array}{l}\text { Q buangan } \\
\text { (m³/detik) }\end{array}$ & $\begin{array}{c}\text { Debit } \\
\text { Rencana } \\
\left(\mathrm{m}^{3} / \text { detik }\right) \\
\end{array}$ \\
\hline Jl. Indragiri & 0.073 & 147.230 & 0.406 & 0.00969 & 0.161 & 0.0161 & 0.177 \\
\hline Jl. Mahakam & 0.131 & 99.625 & 0.420 & 0.009 & 0.106 & 0.0161 & 0.122 \\
\hline Jl. Pangsuma & 0.129 & 100.280 & 0.414 & 0.009 & 0.103 & 0.0161 & 0.119 \\
\hline Gg. Fajar & 0.071 & 149.296 & 0.404 & 0.002 & 0.034 & 0.0161 & 0.050 \\
\hline Gg. Kirana 2 & 0.080 & 137.661 & 0.406 & 0.003 & 0.048 & 0.0161 & 0.064 \\
\hline Jl. Barito & 0.113 & 109.487 & 0.417 & 0.007 & 0.087 & 0.0161 & 0.104 \\
\hline Gg. Malaya & 0.110 & 112.018 & 0.406 & 0.007 & 0.084 & 0.0161 & 0.100 \\
\hline Gg. Sampit & 0.076 & 142.626 & 0.406 & 0.003 & 0.041 & 0.0161 & 0.057 \\
\hline Gg. Irian & 0.123 & 103.490 & 0.409 & 0.008 & 0.097 & 0.0161 & 0.113 \\
\hline Gg. H. Thaha & 0.098 & 120.334 & 0.402 & 0.008 & 0.108 & 0.0161 & 0.124 \\
\hline Gg. Landak & 0.123 & 103.490 & 0.409 & 0.008 & 0.097 & 0.0161 & 0.113 \\
\hline Gg. Aden 1 & 0.098 & 120.334 & 0.403 & 0.008 & 0.109 & 0.0161 & 0.125 \\
\hline Gg. Aden 2 & 0.140 & 95.114 & 0.406 & 0.008 & 0.087 & 0.0161 & 0.103 \\
\hline Gg. Bayu & 0.111 & 111.121 & 0.405 & 0.008 & 0.102 & 0.0161 & 0.118 \\
\hline Gg. Satu & 0.098 & 120.334 & 0.402 & 0.008 & 0.108 & 0.0161 & 0.124 \\
\hline Gg. Tiga & 0.153 & 89.848 & 0.408 & 0.008 & 0.084 & 0.0161 & 0.100 \\
\hline Gg. Asean & 0.165 & 85.256 & 0.407 & 0.008 & 0.079 & 0.0161 & 0.095 \\
\hline Rangon & 0.169 & 83.851 & 0.405 & 0.008 & 0.077 & 0.0161 & 0.093 \\
\hline Kamboja Baru & 0.094 & 123.852 & 0.403 & 0.008 & 0.112 & 0.0161 & 0.128 \\
\hline Sutera & 0.080 & 138.686 & 0.404 & 0.003 & 0.047 & 0.0161 & 0.064 \\
\hline Kamboja & 0.182 & 79.963 & 0.550 & 0.009 & 0.110 & 0.0161 & 0.126 \\
\hline Martapura 3 & 0.144 & 93.274 & 0.409 & 0.011 & 0.115 & 0.0161 & 0.131 \\
\hline Martapura 2 & 0.153 & 89.848 & 0.409 & 0.012 & 0.121 & 0.0161 & 0.137 \\
\hline Martapura Baru & 0.182 & 79.963 & 0.409 & 0.015 & 0.140 & 0.0161 & 0.156 \\
\hline Perintis 1 & 0.180 & 80.355 & 0.406 & 0.015 & 0.139 & 0.0161 & 0.155 \\
\hline H. Mursid 1 & 0.160 & 86.940 & 0.407 & 0.013 & 0.126 & 0.0161 & 0.142 \\
\hline H. Mursid & 0.181 & 80.142 & 0.407 & 0.015 & 0.140 & 0.0161 & 0.156 \\
\hline Rawa Indah & 0.156 & 88.479 & 0.407 & 0.012 & 0.123 & 0.0161 & 0.139 \\
\hline Garuda 1 & 0.180 & 80.355 & 0.406 & 0.015 & 0.139 & 0.0161 & 0.155 \\
\hline Garuda Baru & 0.115 & 108.808 & 0.407 & 0.007 & 0.088 & 0.0161 & 0.105 \\
\hline Garuda II & 0.180 & 80.355 & 0.406 & 0.015 & 0.139 & 0.0161 & 0.155 \\
\hline Peniti Baru & 0.168 & 84.293 & 0.406 & 0.014 & 0.131 & 0.0161 & 0.147 \\
\hline Peniti 1 & 0.144 & 93.274 & 0.409 & 0.011 & 0.115 & 0.0161 & 0.131 \\
\hline Peniti 2 & 0.156 & 88.479 & 0.407 & 0.012 & 0.123 & 0.0161 & 0.139 \\
\hline Kuantan & 0.165 & 85.466 & 0.407 & 0.013 & 0.129 & 0.0161 & 0.145 \\
\hline Tanjung Pura & 0.977 & 26.063 & 0.441 & 0.128 & 0.408 & 0.0161 & 0.424 \\
\hline
\end{tabular}
$147,230 \mathrm{~mm} / \mathrm{jam} .0,00969 \mathrm{~km}^{2}=0.161$ $\mathrm{m}^{3} /$ detik.

Tabel 4. Hasil perhitungan debit rencana

Sumber: Analisa perhitungan 2019

\section{Analisa Debit Buangan (Q limbah)}

Perhitungan Proyeksi Penduduk dengan perencanaan $\mathrm{n}=5$ tahun

Menggunakan rumus

$$
\begin{aligned}
& P n=P o(1+r)^{n} \\
& P_{2024}=10282 \text { jiwa }(1+3,05 \%)^{5}
\end{aligned}
$$

$$
=11948 \text { jiwa }
$$

Kebutuhan air bersih domestik $\left(\mathrm{Q}_{\text {domestik }}\right)=170$ 1t/org/hari.

\section{Menghitung kebutuhan air domestic (Q domestic)}


$\mathrm{Q}_{\text {domestik }}=11948$ jiwa $\times 170$ lt/org/hr x 80\% $=0,0189 \mathrm{~m}^{3} /$ detik

$\mathrm{Q}_{\text {cadangan }}=20 \% \times \mathrm{Q}_{\text {domestik }}$ $=20 \% \times 0,0189=0,00378 \mathrm{~m}^{3} / \mathrm{detik}$

$\mathrm{Q}_{\text {Total }}=\mathrm{Q}_{\text {domestik }}+\mathrm{Q}_{\text {cadangan }}$

$$
=0,0189+0,00378=0,023 \mathrm{~m}^{3} / \text { detik }
$$

\section{Debit air buangan (Qlimbah)}

$\mathrm{Q}_{\text {limbah }}=70 \% \times \mathrm{Q}_{\text {Total }}=70 \% \times 0,023 \mathrm{~m}^{3} /$ detik $=0,0161 \mathrm{~m}^{3} /$ detik.

Tabel 5. Perhitungan Dimensi Penampang Saluran dan kontrol saluran

\begin{tabular}{|c|c|c|c|c|c|c|c|}
\hline Lokasi & $\begin{array}{c}\mathbf{Q} \\
\left(\mathrm{m}^{3} / \text { detik }\right)\end{array}$ & Fd $\left(\mathbf{m}^{2}\right)$ & $\mathbf{d}(\mathbf{m})$ & $\mathbf{b}(\mathbf{m})$ & $\mathbf{w}(\mathbf{m})$ & $\mathbf{h}(\mathbf{m})$ & $\mathbf{P}(\mathbf{m})$ \\
\hline Jl. Indragiri & 0.177 & 0.118 & 0.243 & 0.486 & 0.343 & 0.586 & 0.971 \\
\hline J1. Mahakam & 0.122 & 0.081 & 0.201 & 0.403 & 0.285 & 0.486 & 0.806 \\
\hline J1. Pangsuma & 0.119 & 0.079 & 0.199 & 0.399 & 0.282 & 0.481 & 0.797 \\
\hline Gg. Fajar & 0.050 & 0.033 & 0.129 & 0.259 & 0.183 & 0.312 & 0.517 \\
\hline Gg. Kirana 2 & 0.064 & 0.042 & 0.146 & 0.291 & 0.206 & 0.352 & 0.582 \\
\hline J1. Barito & 0.104 & 0.069 & 0.186 & 0.372 & 0.263 & 0.448 & 0.743 \\
\hline Gg. Malaya & 0.100 & 0.067 & 0.182 & 0.365 & 0.258 & 0.440 & 0.730 \\
\hline Gg. Sampit & 0.057 & 0.038 & 0.138 & 0.276 & 0.195 & 0.333 & 0.552 \\
\hline Gg. Irian & 0.113 & 0.075 & 0.194 & 0.388 & 0.274 & 0.468 & 0.776 \\
\hline Gg. H. Thaha & 0.124 & 0.083 & 0.204 & 0.407 & 0.288 & 0.491 & 0.814 \\
\hline Gg. Landak & 0.113 & 0.075 & 0.194 & 0.388 & 0.274 & 0.468 & 0.776 \\
\hline Gg. Aden 1 & 0.125 & 0.083 & 0.204 & 0.408 & 0.289 & 0.493 & 0.816 \\
\hline Gg. Aden 2 & 0.103 & 0.069 & 0.186 & 0.371 & 0.263 & 0.448 & 0.743 \\
\hline Gg. Bayu & 0.118 & 0.079 & 0.198 & 0.396 & 0.280 & 0.478 & 0.792 \\
\hline Gg. Satu & 0.124 & 0.083 & 0.204 & 0.407 & 0.288 & 0.491 & 0.814 \\
\hline Gg. Tiga & 0.100 & 0.067 & 0.183 & 0.365 & 0.258 & 0.441 & 0.730 \\
\hline Gg. Asean & 0.095 & 0.063 & 0.178 & 0.356 & 0.252 & 0.430 & 0.712 \\
\hline Rangon & 0.093 & 0.062 & 0.176 & 0.352 & 0.249 & 0.425 & 0.704 \\
\hline Kamboja Baru & 0.128 & 0.085 & 0.206 & 0.413 & 0.292 & 0.498 & 0.826 \\
\hline Sutera & 0.064 & 0.042 & 0.146 & 0.291 & 0.206 & 0.351 & 0.582 \\
\hline Kamboja & 0.126 & 0.084 & 0.205 & 0.410 & 0.290 & 0.495 & 0.820 \\
\hline Martapura 3 & 0.131 & 0.087 & 0.209 & 0.417 & 0.295 & 0.504 & 0.835 \\
\hline Martapura 2 & 0.137 & 0.091 & 0.214 & 0.427 & 0.302 & 0.516 & 0.855 \\
\hline Martapura Baru & 0.156 & 0.104 & 0.228 & 0.457 & 0.323 & 0.551 & 0.913 \\
\hline Perintis 1 & 0.155 & 0.103 & 0.227 & 0.454 & 0.321 & 0.548 & 0.909 \\
\hline H. Mursid 1 & 0.142 & 0.095 & 0.218 & 0.435 & 0.308 & 0.526 & 0.871 \\
\hline H. Mursid & 0.156 & 0.104 & 0.228 & 0.455 & 0.322 & 0.550 & 0.911 \\
\hline Rawa Indah & 0.139 & 0.093 & 0.215 & 0.431 & 0.305 & 0.520 & 0.862 \\
\hline Garuda 1 & 0.155 & 0.103 & 0.227 & 0.454 & 0.321 & 0.548 & 0.909 \\
\hline Garuda Baru & 0.105 & 0.070 & 0.187 & 0.373 & 0.264 & 0.451 & 0.746 \\
\hline Garuda II & 0.155 & 0.103 & 0.227 & 0.454 & 0.321 & 0.548 & 0.909 \\
\hline Peniti Baru & 0.147 & 0.098 & 0.221 & 0.443 & 0.313 & 0.534 & 0.886 \\
\hline Peniti 1 & 0.131 & 0.087 & 0.209 & 0.417 & 0.295 & 0.504 & 0.835 \\
\hline Peniti 2 & 0.139 & 0.093 & 0.215 & 0.431 & 0.305 & 0.520 & 0.862 \\
\hline Kuantan & 0.145 & 0.097 & 0.220 & 0.440 & 0.311 & 0.531 & 0.879 \\
\hline Tanjumg Pura & 0.424 & 0.283 & 0.376 & 0.752 & 0.532 & 0.908 & 1.504 \\
\hline
\end{tabular}

Sumber: Hasil Perhitungan

\section{Debit Rencana (Q Rencana)}

$$
\begin{aligned}
\mathrm{Q}_{\text {Rencana }} & =\mathrm{Q}_{\text {hujan }}+\mathrm{Q}_{\text {buangan }} \\
& =0,161 \mathrm{~m}^{3} / \text { detik }+0,0161 \mathrm{~m}^{3} / \text { detik } \\
& =0,177 \mathrm{~m}^{3} / \text { detik }
\end{aligned}
$$

Perhitungan selanjutnya dapat dilihat pada Tabel 6 perhitungan debit rencana.

\section{Analisa Hidrolika Perhitungan Dimensi Saluran}

Saluran yang dipilih untuk contoh perhitungan adalah saluran drainase jalan Indragiri adalah saluran persegi empat jenis terbuka, pemilihan ini dibuat dikarenakan keterbatasan lahan serta untuk mempermudah dalam pemeliharaan saluran yang 
direncanakan. Analisa hidrolika dilakukan untuk menentukan dimensi dan penampang saluran drainase, untuk perhitungan dimensi saluran drainase dapat dilakukan dengan tahapan sebagai berikut: $\mathrm{n}=0.010$ nilai $\mathrm{n}$ untuk rumus manning (saluran beton cor halus dan rata) baik sekali. $\mathrm{S}=1.5 \%$ Dimensi penampang saluran persegi empat dengan menggunakan rumus manning.

Tabel 6. Lanjutan perhitungan dimensi dan kontrol

\begin{tabular}{|c|c|c|c|c|}
\hline Lokasi & $\mathrm{R}(\mathrm{m})$ & $\mathrm{S}$ & Qc (m³/detik) & $\begin{array}{c}\mathrm{Vc} \\
\text { (m/detik) }\end{array}$ \\
\hline Jl. Indragiri & 0.121 & 0.015 & 0.177 & 1.500 \\
\hline Jl. Mahakam & 0.101 & 0.019 & 0.122 & 1.500 \\
\hline Jl. Pangsuma & 0.100 & 0.019 & 0.119 & 1.500 \\
\hline Gg. Fajar & 0.065 & 0.035 & 0.050 & 1.500 \\
\hline Gg. Kirana 2 & 0.073 & 0.030 & 0.064 & 1.500 \\
\hline Jl. Barito & 0.093 & 0.021 & 0.104 & 1.500 \\
\hline Gg. Malaya & 0.091 & 0.022 & 0.100 & 1.500 \\
\hline Gg. Sampit & 0.069 & 0.032 & 0.057 & 1.500 \\
\hline Gg. Irian & 0.097 & 0.020 & 0.113 & 1.500 \\
\hline Gg. H. Thaha & 0.102 & 0.019 & 0.124 & 1.500 \\
\hline Gg. Landak & 0.097 & 0.020 & 0.113 & 1.500 \\
\hline Gg. Aden 1 & 0.102 & 0.019 & 0.125 & 1.500 \\
\hline Gg. Aden 2 & 0.093 & 0.021 & 0.103 & 1.500 \\
\hline Gg. Bayu & 0.099 & 0.020 & 0.118 & 1.500 \\
\hline Gg. Satu & 0.102 & 0.019 & 0.124 & 1.500 \\
\hline Gg. Tiga & 0.091 & 0.022 & 0.100 & 1.500 \\
\hline Gg. Asean & 0.089 & 0.023 & 0.095 & 1.500 \\
\hline Rangon & 0.088 & 0.023 & 0.093 & 1.500 \\
\hline Kamboja Baru & 0.103 & 0.019 & 0.128 & 1.500 \\
\hline Sutera & 0.073 & 0.030 & 0.064 & 1.500 \\
\hline Kamboja & 0.103 & 0.019 & 0.126 & 1.500 \\
\hline Martapura 3 & 0.104 & 0.018 & 0.131 & 1.500 \\
\hline Martapura 2 & 0.107 & 0.018 & 0.137 & 1.500 \\
\hline Martapura Baru & 0.114 & 0.016 & 0.156 & 1.500 \\
\hline Perintis 1 & 0.114 & 0.016 & 0.155 & 1.500 \\
\hline H. Mursid 1 & 0.109 & 0.017 & 0.142 & 1.500 \\
\hline H. Mursid & 0.114 & 0.016 & 0.156 & 1.500 \\
\hline Rawa Indah & 0.108 & 0.018 & 0.139 & 1.500 \\
\hline Garuda 1 & 0.114 & 0.016 & 0.155 & 1.500 \\
\hline Garuda Baru & 0.093 & 0.021 & 0.105 & 1.500 \\
\hline Garuda II & 0.114 & 0.016 & 0.155 & 1.500 \\
\hline Peniti Baru & 0.111 & 0.017 & 0.147 & 1.500 \\
\hline Peniti 1 & 0.104 & 0.018 & 0.131 & 1.500 \\
\hline Peniti 2 & 0.108 & 0.018 & 0.139 & 1.500 \\
\hline Kuantan & 0.110 & 0.017 & 0.145 & 1.500 \\
\hline Tanjungpura & 0.188 & 0.008 & 0.424 & 1.500 \\
\hline
\end{tabular}

Sumber: Hasil Perhitungan

$$
\text { Luas Penampang Basah } F d=\frac{\boldsymbol{Q}}{\boldsymbol{V}}
$$

Dimana: $Q=0,177 \mathrm{~m}^{3} / \mathrm{dt}, V=1,50 \mathrm{~m} /$ detik

$$
F d=\frac{0.177}{1.5}=0.118
$$

Dimensi penampang saluran

Debit air $(Q)=0,177 \mathrm{~m}^{3} /$ detik

Penampang basah $(F d)=0,118 \mathrm{~m}^{2}$ segiempat

$$
B=2 . d
$$

$$
\begin{aligned}
d & =0,707 \sqrt{ } \mathrm{Fd} \\
& =0,707 \sqrt{ } 0.118 \\
& =0,243 \mathrm{~m} \\
b & =2 \times 0,243 \mathrm{~m}=0.486 \mathrm{~m} \\
w & =\sqrt{ } \mathrm{b} \cdot \mathrm{d} \\
w & =\sqrt{ } 0,486 \mathrm{~m} \times 0.243 \mathrm{~m}=0.344 \mathrm{~m} \\
h & =w+d \\
h & =0.243+0.344=0.587 \mathrm{~m}
\end{aligned}
$$


Jadi penampang saluran hasil dari perencanaan seperti ditunjukan pada Gambar 21.

Kemiringan Saluran

$$
\mathrm{Qc}=\mathrm{S}^{1 / 2} . \mathrm{Fd}(\mathrm{R})^{2 / 3} \frac{1}{n} ; \mathrm{S}=\left(\frac{V \cdot n}{R^{\wedge} 2 / 3}\right)
$$

Keliling basah $(\mathrm{P})=\mathrm{b}+2 \mathrm{~d}=0.5+2.0 .243=$ $0.986 \mathrm{~m}$

Luas penampang basah $(\mathrm{Fd})=0.118 \mathrm{~m}^{2}$

Jari-jari hidrolis $(\mathrm{R})=\frac{F d}{P}=\frac{0.118}{0.986}=0.120 \mathrm{~m}$

Kemiringan Saluran $=$

$\mathrm{S}=\left(\frac{1.5 \times 0.02}{0.120^{\wedge} 2 / 3}\right)^{2}=0.015$

Kontrol: $\mathrm{Qc}=\mathrm{S}^{1 / 2} . \mathrm{Fd} \cdot \mathrm{R}^{2 / 3} \cdot \frac{1}{n}$

$\mathrm{Q}=0.177 \mathrm{~m}^{3} /$ detik

$\mathrm{S}=0,015$

$$
\begin{aligned}
& \mathrm{Fd}=0.118 \mathrm{~m} 2 \\
& \mathrm{R}=0,120 \mathrm{~m} \\
& \mathrm{n}=0,020 \\
& \mathrm{Qc}=\left(0,015^{1 / 2}\right) \times(0,118) \times\left(0,120^{2 / 3}\right) \times(1 / 0.02) \\
& =0,177 \mathrm{~m}^{3} / \mathrm{dt}
\end{aligned}
$$

Kontrol : Qc $\geq$ Qr $=0,177 \mathrm{~m}^{3} / \mathrm{dt} \geq 0,177 \mathrm{~m}^{3} / \mathrm{dt}$.

Kontrol kecepatan

$\mathrm{V}=\frac{Q}{A}$

$\mathrm{A}=\mathrm{b} \cdot \mathrm{d}$

Catchment area Indragiri

$\mathrm{Q}=0.177 \mathrm{~m} 3 / \mathrm{dt}$

$\mathrm{b}=0.5 \mathrm{~m}$

$\mathrm{d}=0,243 \mathrm{~m}$

$\mathrm{A}=0,118 \mathrm{~m}^{2}$

$\mathrm{V}=\frac{0.177}{0.118}=1.5<\mathrm{Vijin}=1,5 \mathrm{~m} / \mathrm{dt}$

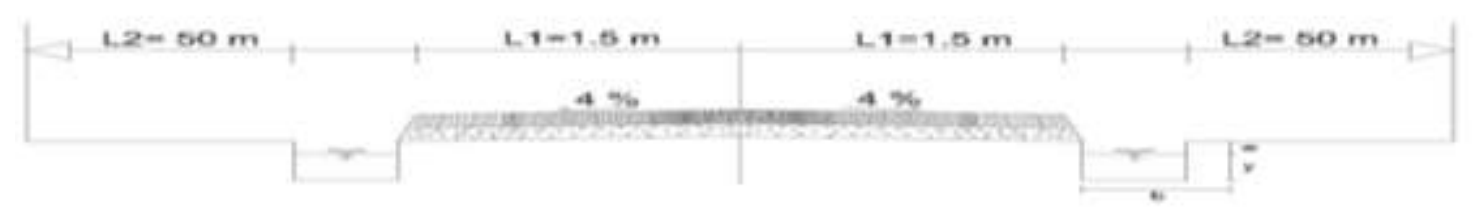

Gambar 2 Potongan melintang cathment area Indragiri

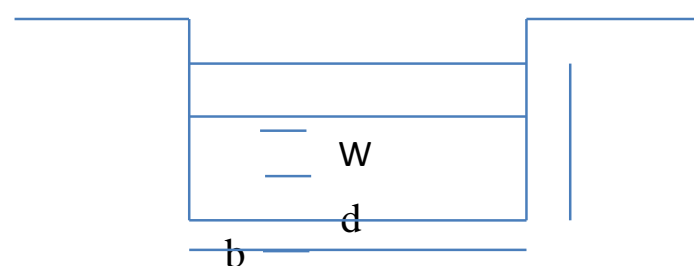

Gambar 3 Penampang saluran

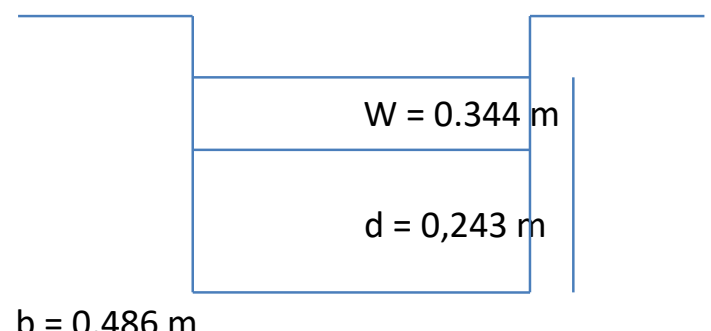

$\mathrm{b}=0.486 \mathrm{~m}$

Gambar 4. Dimensi penampang saluran pada Indragiri

\section{UCAPAN TERIMA KASIH}

Penulis mengucapkan terima kasih yang sebesarnya pada Politeknik Negeri Pontianak yang mensupport dan mendanai penelitian ini dengan DIPA Polnep 2019.

\section{DAFTAR PUSTAKA}

Anonim. 1994. SNI $03-3424-1994$ "Perencanaan Drainase Permukaan Jalan "Departemen Pekerjaan Umum.

Anonim. 2014. Permen PU Nomor 12/Prt/M/2014 tentang Penyelenggaraan (Tata cara perencanaan Sistem Drainase 
Perkotaan), Departemen Pekerjaan Umum, Jakarta

Chow,Van Te dan E.V. Nensi Rosalina. 1997. Hidrolika Saluran Terbuka. Jakarta: Erlangga.

Indra, Muhammad Mirza, tt. Kajian Analisa Konsep Penanganan Drainase untuk Kawasan Sungai Serok Kecamatan Pontianak Barat Kota Pontianak, Jurnal 190871-ID, Alumni Prodi Teknik Sipil FT.Untan
Kusumajaya, A. 2015, eprints.polsri.ac.id

Ryanti, Eva. 2016. Rekayasa Hidrologi, Politeknik Negeri Pontianak, Pontianak

Senja, Astri Mei., Guntur Syahputra, S. 2014. Analisis Fungsi Drainase untuk Mencegah Terjadinya Banjir di Kota Pontianak, Makalah Perencanaan Kota, Program Pasca Sarjana Ilmu Lingkungan Universitas Tanjungpura, Pontianak

Suripin. 2004. Sistem Drainase Perkotaan yang Berkelanjutan. Yogyakarta: Andi Offset. 